Ann. Biol. anim. Bioch. Biophys., 1978, 18 (2 B), 441-452.

\title{
Control of meiosis reinitiation in starfish : calcium ion as the primary effective trigger
}

\author{
by P. GUERRIER, M. MOREAU, M. DORÉE
}

Station biologique, 29211 Roscoff. France.

Summary. In vitro experiments demonstrate that the spontaneous maturation of Marthasterias glacialis oocytes results from the release of preformed 1-MeAde from the follicles. Follicle-free prepared oocytes, taken early in the season, can however reinitiate meiosis under the influence of an increased level of extracellular $\mathrm{Ca}^{2+}$ ions. This triggers a transient change in intracellular free $\mathrm{Ca}^{2+}$ which can be monitored in aequorin-injected oocytes and appears to be similar to that resulting from 1-MeAde application. This hormone proved to be efficient in the complete absence of external $\mathrm{Ca}^{2+}$ ions. Nuclear maturation and cortical reaction (either by sperm or ionophore A 23187) can be triggered independently. The maturation-free $\mathrm{Ca}^{2+}$ peak appears less than $1 \mathrm{sec}$ after the application of the efficients stimuli ( $\mathrm{Ca}^{2+}$ or 1-MeAde). It is about 20 times lower than the ionophore-induced peak and corresponds to the release of 0.5 to $1.5 \mu \mathrm{M} \mathrm{Ca}^{2+}$. Inhibition of both the $\mathrm{Ca}^{2+}$ and the meiosis responses by $\mathrm{D} 600$ or EGTA supports the view that intracellular $\mathrm{Ca}^{2+}$ release may be the primary trigger for meiosis reinitiation.

\section{Introduction}

In starfish, female gametes inside the gonad remain arrested in the late prophase 1 of meiosis (germinal vesicle stage). Spawning and meiosis reinitiation depend on the release of a meiosis-inducing substance (MIS) which is produced in the follicles under the influence of a gonad-stimulating substance (GSS) of neural origin (Kanatani and Shirai, 1967 ; Schuetz and Biggers, 1967). MIS, which has been identified as 1-methyladenine (1-MeAde) by Kanatani and Shirai (1969), is known to act directly at the oocyte surface (Kanatani and Hiramoto, 1970 ; Dorée and Guerrier, 1975) where if renders the oocyte fertilizable (Hirai ef al., 1971) and produces a cytoplasmic maturation-promoting factor (MPF) which controls meiosis reinitiation and is amplifiable from oocyte to oocyte (Kishimoto and Kanatani, 1976). Presently, we do not know the exact nature of the original trigger mechanism resulting from 1-MeAde action. It has only been shown that this hormone reduces the disulfide bonds in the cortical layer (Kishimoto et al., 1976) and stimulates protein phosphorylation through activation of endogeneous protein kinases (Guerrier ef al., 1977). These events, which are already triggered after 5 min contact with the hormone, are controled at the posttranslational level (Guerrier and Dorée, 1975). In this paper, we will present new data indicating that the first step in 1-MeAde action consists in a transient release of intracellular $\mathrm{Ca}^{2+}$ ions. 


\section{Material and methods.}

Oocyte preparation. As described previously, oocytes of Marthasterias glacialis were prepared free of follicular cells by washing and centrifuging them in artificial calcium-free sea water (Dorée and Guerrier, 1975). Follicular cells were recovered from the first supernatant by pelletting them $10 \mathrm{~min}$ at $10000 \mathrm{rpm}$ in an International centrifuge.

Reagents. Isotonic salt solutions were prepared according to Harvey (1956), artificial sea water (ASW) and calcium-free sea water (CaFSW) according to Shapiro (1941). In calcium-free, sodium-free sea water (CaNaFSW), Tris (hydroxymethyl) aminomethane- $\mathrm{HCl}$ was substituted for $\mathrm{NaCl}$. Calcium-free, magnesium-free sea water (CaMgFSW) was prepared by substituting $\mathrm{NaCl}$ and $\mathrm{Na}_{2} \mathrm{SO}_{4}$ to $\mathrm{MgCl}_{2}$ and $\mathrm{MgSO}_{4}$ in the original CaFSW. CaFSW was also prepared without sulfates when complemented with lanthanum chloride.

1-MeAde was taken from a $10^{-3} \mathrm{M}$ solution in CaFSW. Lilly Ca $\mathrm{Ca}^{2+}$ ionophore $\mathrm{A} 23187$ was prepared as a $2 \mathrm{mM}$ stock solution in DMSO-Ethanol $(1: 3)$ and diluted in the assay medium (10 $\mathrm{nM}$ final concentration). D600 and isoptin from Knoll (Ludwigshafen) were dissolved in $0.1 \mathrm{ml}$ ethanol and adjusted to $10 \mathrm{ml} \mathrm{CaFSW}$ to give a $2 \mathrm{mM}$ stock solution containing 1 p. 100 ethanol. EDTA and EGTA were from Sigma. All these solutions were finally adjusted to $\mathrm{pH} 7.5-8$ using the lowest efficient concentrations of Tris- $\mathrm{HCl}$ buffer. Control experiments were also performed using CaFSW + organic vehicles which gave no deviation from pure CaFSW controls. GSS has been prepared from radial nerves washed in distilled water and lyophylised. The dry powder was diluted and homogeneized CaFSW and the supernatants from 10-min centrifugation at $10000 \mathrm{rpm}$ were heated $10 \mathrm{~min}$ at $100^{\circ} \mathrm{C}$ and passed through a Sephadex G25 column.

Microinjection experiments. Experiments with the $\mathrm{Ca}^{2+}$-sensitive photoprotein aequorin were performed by the junior author, Moreau, in the laboratory of Prof. C. C. Ashley in Oxford during early June, using Marthasterias glacialis dregged from Oban. (Scotland). $120 \mathrm{pl}$ (6 p. 100 of oocyte volume) of highly purified aequorin, taken from the Oxford stock or purified from a Sigma commercial sample, suspended in a $10 \mu \mathrm{M}$ EDTA, $10 \mathrm{mM}$ sodium acetate $\mathrm{pH} 6.2$ buffer solution, were pressureinjected into the oocytes through bevelled micropipettes. The oocytes were affixed according to the technique of Steinhardt et al. (1971). Flashes were detected without light guide using a EMI photomultiplier dispalyed on an oscilloscope. EGTA was injected in the same manner. $\mathrm{Ca}^{2+}$ ions were also introduced into the oocytes by iontophoresis through an intracellular glass microelectrode filled with $3 \mathrm{M} \mathrm{CaCl}_{2}$, with a tip aperture of 0.3 to $0.5 \mu \mathrm{m}$.

Voltage clamp. Oocytes were clamped with two microelectrodes of $25 \mathrm{M} \Omega$, according to the procedure outlined by Moore and Cole (1963).

Biological assays. About 2000 oocytes were used in each assay which was performed in $1 \mathrm{ml}$ solutions filling the depressions of a disposable plastic plate. Various concentrations of $\mathrm{Ca}^{2+}$ ions were obtained in the assay by adding various amounts 
of a pH 8 isotonic $\mathrm{CaCl}_{2}$ solution $(300 \mathrm{mM}$ ) to the CaFSW or CaNaFSW vehicle. Per cent meiosis as expressed by GVBD was determined by counting at least 300 oocytes $1 \mathrm{hr}$ after starting the incubation. This percentage did not increase during longer incubation periods, and delayed counts (to $+2 \mathrm{~h}$ ) repeatedly showed that all the responsive oocytes had expelled polar bodies.

\section{Results.}

\section{Effects of $\mathrm{Ca}^{+2}$ ions on intact follicles and isolated follicular cells}

When isolated in $10 \mathrm{mM} \mathrm{Ca} 2+$, full grown oocytes of Marthasterias glacialis, still enclosed in their follicles, exhibit germinal vesicle breakdown (GVBD) in about $18 \mathrm{~min}$ and further expell the polar bodies, while the follicular envelope contracts and forms a clump. This phenomenon, common to most species among the genus Asterias, has been called « spontaneous maturation "; it did not occur when follicles were isolated in CaFSW (Dalcq, 1925 ; Kanatani, 1964 ; Cloud and Schuetz, 1973 ; Shirai, 1974). If remained uncertain, however, whether $\mathrm{Ca}^{2+}$ ions replaced $\mathrm{GSS}$ in stimulating 1-MeAde production in the follicles or only promoted its release from preformed stores.

Figure 1 shows that the second eventuality is the most likely since it demonstrates that MIS is as efficiently released from the follicular cells after 60,3 or even 0 -min incubation in $150 \mathrm{mM} \mathrm{Ca} \mathrm{C}^{2+} \mathrm{ASW}$, while it remains undetectable after 1-hour incubation in CaFSW. Adding back $\mathrm{Ca}^{2+}$ ions to this last extract and boiling again, however, result in an effective MIS release. Since incubating follicular cells in $10 \mathrm{mM} \mathrm{Ca}{ }^{2+}$ ASW repeatedly gave the same positive results (whether the incubation medium was boiled or not), whereas adding GSS $(0.3 \mathrm{mg} / \mathrm{ml})$ or increasing the incubation time did not

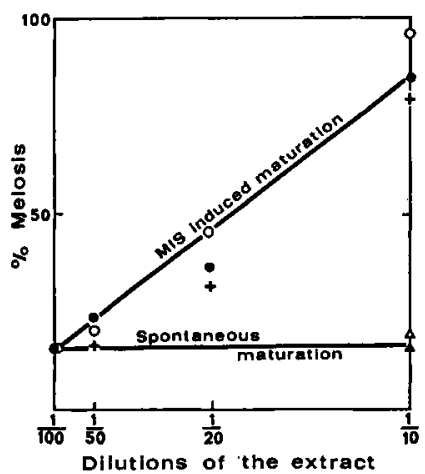

FIG. 1. - Effects of $\mathrm{Ca}^{2+}$ ions on MIS release by isolated follicle cells. Follicle cells isolated from $2.5 \times 10^{5}$ oocytes were suspended in $1 \mathrm{ml} \mathrm{CaFSW}$ aliquots. 1 vol of $300 \mathrm{mM} \mathrm{CaCl} 2$ was then added and the resulting medium $\left(150 \mathrm{mM} \mathrm{Ca}{ }^{2}+\mathrm{ASW}\right)$ boiled either instantaneously $(\bullet)$ or after 3 -min $(\mathrm{O})$ or 1 -hour incubation $(+)$. Bioassay was performed by adding about 2000 follicle -free oocytes $(20 \mu l)$ into $1 \mathrm{ml}$ of various CaFSW dilutions of the low speed supernatant obtained from boiled extracts. Controls were : undiluted supernatant boiled after 1-hour incubation in CaFSW $(\Delta)$; $1 / 10$ dilution of $150 \mathrm{mM} \mathrm{Ca}{ }^{2}+A S W$, i.e. $15 \mathrm{mM} \mathrm{Ca}^{2+} A S W(\triangle) .100$ p. 100 meiosis reinitiation indicates a MIS concentration equivalent to $0.1 \mu \mathrm{M} 1$-MeAde. 
significantly affect the results, it is thus clear that, in our material, spontaneous maturation is effected through the in vivo release of preformed 1-MeAde under the influence of $\mathrm{Ca}^{2+}$ ions present in sea water. The importance of this stock is illustrated by the fact that we found repeatedly (6 experiments) that the follicles from $10^{6}$ oocytes suspended in $1 \mathrm{ml}$ of $10 \mathrm{mMCa}^{2+}$ ASW were able to release an amount of MIS equivalent to about $4 \times 10^{-6} \mathrm{M}$ 1-MeAde.

\section{Effects of $\mathrm{Ca}^{2+}$ ions on oocytes free of follicular cells}

If one excepts an early report by Kanatani (1964), all recently published data claim that, once prepared in Ca-FSW, follicle-free starfish oocytes can no longer resume meiosis under the influence of $\mathrm{Ca}^{2+}$ ions (Schuetz, 1969 ; Cloud and Schuetz, 1973). We found however since 1974 that some follicle-free oocyte populations were able to resume meiosis up to 50 p. 100 when transferred to or even when continuously perfused with fresh natural sea water. Experiments performed this year concern more than 20 different females in which follicle-free oocytes definitively responded to increased levels of external $\mathrm{Ca}^{2+}$ ions by resuming meiosis. In every case, GVBD occurred about $18 \mathrm{~min}$ after the addition of the threshold-efficient $\mathrm{Ca}^{2+}$ ion concentration, which reproduced perfectly the kinetics usually obtained through 1-MeAde stimulation. Both polar bodies were further extruded normally at the right time, while some cortical reactions, lobulations, monasterian cycles and vegetative autotomy were often observed (as already described by Dalcq, 1925), which did not occur under 1-MeAde stimulation. When transferred to sea water and fertilized after GVBD, these oocytes were found to develop normally to bipinnaria larvae (PI. I, 7 and 8). That these responses depend on the direct action of $\mathrm{Ca}^{2+}$ ions on the follicle-free oocytes is illustrated in the following sections.

1. Concentration dependence. - Dose-response curves were systematically established for both 1-MeAde and $\mathrm{Ca}^{2+}$ ions. In 20 such experiments, performed during May and early June, we found that the 50 p. 100 meiosis point was reached using 1-MeAde concentrations ranging from $4 \times 10^{-8}$ to $10^{-7} \mathrm{M}$ or $\mathrm{Ca}^{2+}$ concentrations from 15 to $300 \mathrm{mM}$. As illustrated on figure $2 A, B$ and $C$, no correlation was noticed

\section{PLATE் 1}

Calcium induced maturation in Marthasterias glacialis oocyfes (oocyte diameter : $150 \mu$ )

1, 2, 3. - Follicle free oocytes preactivated mith $10 \mathrm{nM}$ ionophore A23 187 (from the $2 \mathrm{mM}$ stock solution) in CaMgFSW were photographed just affer $90 \mathrm{mM} \mathrm{Ca}{ }^{2+}$ addition (1), $20 \mathrm{~min}$. later (2) and $70 \mathrm{~min}$. later, during first polar body extrusion (3).

4, 5, 6. - Follicle free oocytes preactivated by insemination in ASW (4) were transfered to CaMgFSW and recieved $60 \mathrm{mM} \mathrm{Ca}{ }^{2+}(5)$. Germinal vesicle breakdown occurs $18 \mathrm{~min}$. later (6).

7.8. - Two successive stages in the development of normal bipinnaria larvae resulting from fertilization of $\mathrm{Ca}^{2+}$ matured follicle free oocytes. 
between the sensitivity of the oocytes populations relative to these stimuli. Figure $2 \mathrm{~A}$ shows more specifically that meiosis reinitiation is as efficiently triggered after the vitelline membrane has been digested $(10 \mathrm{~min} 0.5 \mathrm{mg} / \mathrm{ml}$ pronase treatment followed by careful and repeated washing) as before. Figure $2 B$ demonstrates that the effects of 1-MeAde and $\mathrm{Ca}^{2+}$ ions are additive. Figure $2 C$ was obtained at the end of June and is characteristic for some oocyte populations that we found to respond significantly to $\mathrm{Ca}^{2+}$ ions only when the CaFSW vehicle was replaced by CaNaFSW. Later on in the season, we also found populations which no longer responded to $\mathrm{Ca}^{2+}$ ions either in CaFSW or in CaNaFSW and thus behaved as all the Asterias rubens oocyte populations we had the opportunity to study so for.

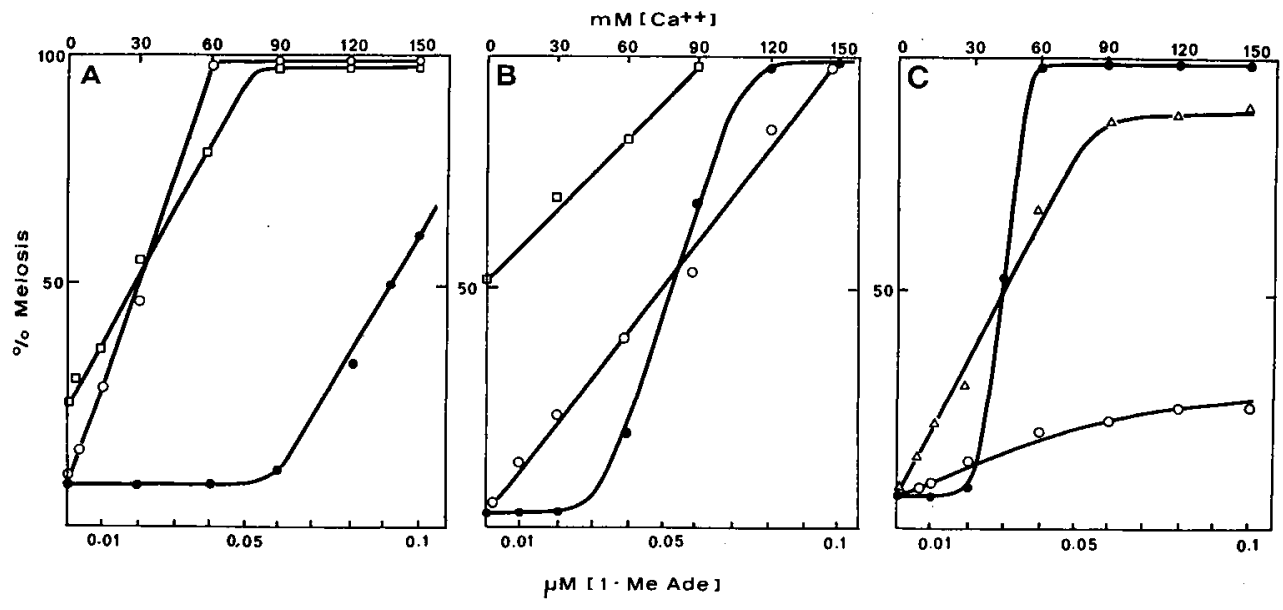

FIG. 2. - Dose response curves of isolated follicle-free oocytes from different females in presence of increasing amounts of either 1-MeAde (bottom abcissa) or $\mathrm{Ca}^{2+}$ ions (top abcissa). In this series, solid circles illustrate the response to 1-MeAde $(\bullet)$. 2A : oocytes stimulated by $\mathrm{Ca}^{2+}$ ions before $(O)$ or after $(\square)$ a $10-\mathrm{min} 0.5 \mathrm{mg} / \mathrm{ml}$ pronase treatment. $2 B: O, \mathrm{Ca}^{2+}$-stimulated oocytes; $\square$, oocytes stimulated simultaneously by $5 \times 10^{-8} \mathrm{M}$ 1-MeAde plus increasing $\mathrm{Ca}^{2+}$ ion concentration. $2 C: \mathrm{Ca}^{2+}$-stimulated oocytes either in the CaFSW vehicle $(O)$ or in the CaNaFSW vehicle $(\triangle)$.

2. Time of contact required to obtain the biological response. - The minimum efficient exposure to $\mathrm{Ca}^{2+}$ ions or 1-MeAde required for triggering meiosis reinitiation has been determined simultaneously on six different oocyte populations. With both stimuli, we found no significant differences whether threshold or higher concentrations were used. In five experiments performed at $20^{\circ} \mathrm{C}$, the $\mathrm{Ca}^{2+}$ or 1-MeAdedependent phases (Guerrier and Dorée, 1975) were of the order of $4 \mathrm{~min}$ and $30 \mathrm{sec}$ with a small advantage in favour of the $\mathrm{Ca}^{2+}$ stimulus (fig. $2 A$ ). In one additionnal experiment however (fig. $2 B$ ), the $\mathrm{Ca}^{2+}$ treatment proved to be much more efficient since 50 p. 100 meiosis was reached in 3 min instead of $6 \mathrm{~min}$ with 1-MeAde. In this case moreover, germinal vesicle-bearing oocytes stimulated by $\mathrm{Ca}^{2+}$ ions raised a fertilization membrane as early as after a 4-min contact period. The percentage of truly activated oocytes increased further with time, most of the oocyte population being affected after the 8 th minute. This did not preclude, but only slightly reduced, 
the efficacity of the treatment in inducing GVBD and polar body extrusion (continuous contact gave 78 p. 100 meiosis).

3. Nuclear maturation of preactivated oocytes. - It has been shown that starfish oocytes prepared in CaFSW can be easily activated at the germinal vesicle stage either by fertilization (Cayer et al., 1975) or through action of the ionophore A 23187 (Schuetz, 1975b). In our material, we found that fertilization had to be performed in normal sea water, while the ionophore activation readily occurred in CaFSW or CaMgFSW. Addition of $2 \mathrm{mM}$ EDTA or EGTA to these last vehicles was found however to inhibit the cortical reaction, except for that small portion of oocytes which had previously undergone spontaneous maturation. On the contrary, when oocytes were transferred to these media $3 \mathrm{~min}$ only after sperm or ionophore addition, this lead to a greater elevation of the fertilization membrane. When such fertilized or activated oocytes with highly elevated fertilization membranes were further assayed for $\mathrm{Ca}^{2+}$ ion sensitivity in the CaFSW vehicle, we consistently oblained a positive nuclear maturation response which included GVBD at $18 \mathrm{~min}$ and polar body extrusion (PI. I, 1 to 6). Negative results were only noticed in some cases, i.e. when the $\mathrm{Ca}^{2+}$ stimulus was applied too early (less than $30 \mathrm{~min}$ ) after the ionophore activation step. lonophore $+\mathrm{Ca}^{2+}$-matured oocytes exhibited monasterian cycles while fertilized $+\mathrm{Ca}^{2+}$-matured eggs showed polyasters indicative of polyspermy.

4. Specificity of the response to $\mathrm{Ca}^{2+}$ ions. - Meiosis reinitiation was never elicited in $\mathrm{Ca}^{2+}$-sensitive oocytes, when using $\mathrm{NH}_{4} \mathrm{Cl}, \mathrm{Na}$ citrate, $\mathrm{Na}$ oxalate, $\mathrm{KCl}, \mathrm{NaCl}$ or
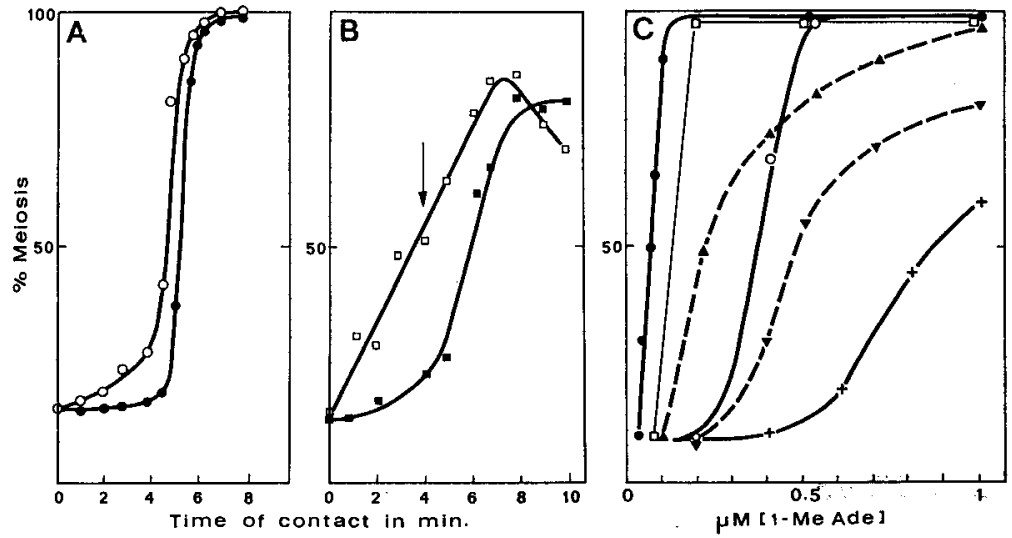

FIG. 3A-B. - Effects of increasing the exposure to 1-MeAde or $\mathrm{Ca}^{2+}$ ions on meiosis reinitiation. Follicle free oocytes were incubated for various lengths of time either in presence of $2 \times 10^{-7} \mathrm{M} 1$-MeAde $(\bullet, \square)$ or $0.3 \mathrm{M} \mathrm{Ca}^{2+}$ ions $(O, \square)$ before returning to a 100 times more dilute medium. In $B$ experiment, the arrow at $4 \mathrm{~min}$ indicates that $\mathrm{Ca}^{2+}$-stimulated germinal vesicle-bearing oocytes begin to elevate their fertilization membrane as a result of cortical granule breakdown induction.

FIG. 3C. - Influence of 1-MeAde concentration on D 600 and isoptin inhibition of meiosis reinitiation. $\bullet$, 1-MeAde stimulated control oocytes from Marthasterias glacialis or Asterias rubens $; \boldsymbol{\nabla}, \mathbf{\Delta}$, Asterias rubens oocytes respectively in $7.5 \times 10^{-5} \mathrm{M} \mathrm{D} 600$ and $10^{-4} \mathrm{M}$ isoptin ; $\square, O,+$, Marthasterias glacialis oocytes respectively in $3 \times 10^{-5} \mathrm{M}, 7.5 \times 10^{-5} \mathrm{M}$ and $3 \times 10^{-4} \mathrm{M} \mathrm{D} 600$. All maturing oocytes were observed to extrude both polar bodies. 
$\mathrm{PO}_{4} \mathrm{Na}_{2} \mathrm{H}$ isotonic solutions, whereas these solutions did not inhibit the 1-MeAdedependent maturation even after $1 \mathrm{~h}$. preincubation. 1-MeAde-dependent maturation could also occur and was even facilitated when the hormone was added after $1 \mathrm{hr}$ preincubation in CaMgFSW containing either EDTA or EGTA (2 $\mathrm{mM})$ or in CaMgFSW containing $10 \mathrm{mM}$ Lanthanum chloride and no sulfate. On the other hand, isotonic $\mathrm{CaCl}_{2}$ usually results in 100 p. 100 meiosis, if one excepts late June populations. In addition, we found however that some oocyte populations were also able to respond to $\mathrm{MgCl}_{2}$ or $\mathrm{MgSO}_{4}$ isotonic solutions. Oocytes which only responded to $\mathrm{Ca}^{2+}$ ions in $\mathrm{Na}$ FSW were also sensitive to $\mathrm{Mg}^{2+}$ ions in this same vehicle.

Using the voltage clamp technique, we found that transferring $\mathrm{Ca}^{2+} \mathrm{ASW}$-irresponsive oocytes to $75 \mathrm{mM} \mathrm{Ca}^{2+}$-enriched $\mathrm{NaFSW}$ increased the $\mathrm{Ca}^{2+}$ inward current component up to values characteristic for $\mathrm{Ca}^{2+}$-responsive oocytes, which paralleled resumption of their capacity to enter meiosis. Conversly, the addition of $10 \mathrm{mM}$ Lanthanum chloride to $75 \mathrm{mMCa}^{2+}$-enriched sulfate-free ASW blocked meiosis reinitiation by decreasing this current down to values observed in the exclusive presence of 1-MeAde. D600 and isoptin (Kohlhardt et al., 1972) behaved differently in that they inhibited both $\mathrm{Ca}^{2+}$ and 1-MeAde-dependent maturation (fig. $3 \mathrm{C}$ ).

5. Direct evidence that intracellular calcium is released under the influence of 1-MeAde. - We were able to detect and record flash emission from a single aequorin pressure-injected oocyte or a population of these in less than $1 \mathrm{sec}$. after the addition of either 1-MeAde or $\mathrm{Ca}^{2+}$ ions and to trace the dose-response curve for 1-MeAde action. Threshold peak value for triggering 100 p. 100 meiosis over the population was obtained using $2 \times 10^{-7} \mathrm{M} 1-\mathrm{MeAde}$ and amounted to a transient $\mathrm{Ca}^{2+}$ variation of about 0.5-1.5 $\mu \mathrm{M}$, according to our calibration data. This amount is about 20 times lower than that obtained through ionophore A 23187 activation and 150 times less than the flash emission recorded from a 20 p. 100 Triton $\times 100$-injured oocyte. That this free $\mathrm{Ca}^{2+}$ peak is essential for meiosis reinitiation results from the fact that it does not appear in the presence of blocking concentrations of D 600, while raising external 1-MeAde concentration allows both processes to occur (fig. 4). Free $\mathrm{Ca}^{2+}$ peak and meiosis reinitiation are also irreversibly abolished when 2 mM EGTA is injected into the oocyte before 1-MeAde application, whereas the same injection has

D. $600 \quad 10^{-3} \mathrm{M}$

in preincubation

1.MA $2 \cdot 10^{-7} \mathrm{M} \quad$ 1-MA $10^{-6} \mathrm{M}$
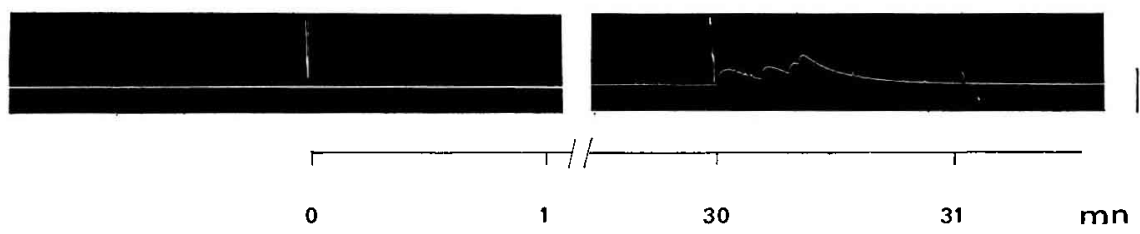

FIG. 4. - Competitive inhibition of the 1-MeAde induced free calcium releose by D 600 . Flashes obtained with $10^{-6}$ M 1-MeAde (1-MA) correspond to the reaction of 12 aequorin-injected oocyles which were further found to undergo germinal vesicle breakdown. Original record. The vertical bar represents $0.5 \mathrm{nA}$ in our system. 
no effect when performed after flash emission. By injecting the EGTA during peak development, we were moreover able to adjust free $\mathrm{Ca}^{2+}$ release under its threshold value, which precluded meiosis reinitiation.

In addition, our $\mathrm{Ca}^{2+}$ iontophoretic experiments agree quite well with these data since short pulses ( $2 \mathrm{nA} / 2 \mathrm{~min}$ ) were found to induce meiosis reinitiation when applied in NaFSW, whereas higher stimulations (15 $\mathrm{nA} / 2 \mathrm{~min}$ ) always resulted in activation without nuclear maturation induction.

\section{Discussion.}

Since the pioneer works of Dalcq $(1925,1928)$ and Pasteels $(1935,1938)$, which stressed the importance of external $\mathrm{Ca}^{2+}$ ions in triggering meiosis reinitiation in various invertebrate oocytes including starfish, it has been confirmed only in a few species that $\mathrm{Ca}^{2+}$ ions act directly at the level of the oocyte. This is clearly the case however for oocytes which are normally deprived of follicular cells, such as those of the annelids Hydroides (Pasteels, 1935) and Chaetopterus (Ikegami ef al., 1976) or those of the lamellibranchs Barnaea (Pasteels, 1938) or Spisula. Meiosis reinitiation under the influence of the Lilly Ca ${ }^{2+}$ ionophore A 23187 has been only obtained on Spisula (Schuetz, 1975a) and Xenopus oocytes (Wasserman and Masui, 1975) in the presence of external $\mathrm{Ca}^{2+}$ ions. On the contrary, this ionophore proved to be quite efficient in promoting activation of the eggs of several unrelated species even when applied in the complete absence of $\mathrm{Ca}^{2+}$ ions (Steinhardt and Epel, 1974 ; Steinhardt et al., 1974 ; Paul, 1975). The recent works of Ridgway et al. (1976) on Medaka and of Steinhardt et al. (1977) on the sea urchin egg demonstrated, by using aequorin, that sperm and ionophore indeed promoted a release of intracellular free calcium.

The present results indicate first that the spontaneous maturation of Marthasterias glacialis oocytes depends directly on the release of preformed MIS stocked in the follicular cells. Secondly, they demonstrate quite unequivocally that follicle-free oocytes can also respond directly to increased levels of external $\mathrm{Ca}^{2+}$ ions by reinitiating meiosis, provided the oocytes are taken before natural spawning, early in the season. Dalcq (1925) who reported about $\mathrm{Ca}^{2+}$-induced maturation even inside the ovary was also the first to recognize this time-related difference in oocyte sensitivity which he attributed to a progressive $\mathrm{Ca}^{2+}$ impregnation of the membrane as tested with cytolytic solutions.

That $\mathrm{Ca}^{2+-d e p e n d e n t ~ m e i o s i s ~ c a n n o t ~ b e ~ d u e ~ t o ~ a n ~ e v e n t u a l ~ r e l e a s e ~ o f ~ 1-M e A d e ~}$ by occasionally contaminating follicle cells stands out clearly from the fact that $\mathrm{Ca}^{2+}$ response can be evoked more rapidly than response to 1-MeAde (fig. 3A, B). Figure $2 A$ indicates moreover that raising external $\mathrm{Ca}^{2+}$ concentration from 0 to $30 \mathrm{mM}$ gave 50 p. 100 meiosis which, in the best case (i. e. assuming a $10^{-9} \mathrm{M} 1$-MeAde concentration in the CaFSW vehicle, which is quite unlikely since oocytes were carefully washed before each experiment) corresponds to a 4-fold increase in 1-MeAde concentration $\left(2 \times 10^{-8}\right.$ to $\left.9 \times 10^{-8}\right)$. This cannot be accounted for on the basis of 1 -MeAde release since $2.5 \times 10^{5}$ follicles from the same population produced about $10^{-6} \mathrm{M} 1-\mathrm{MeAde} / \mathrm{ml}$, whereas our assay contained no more than $2 \times 10^{3}$ follicle-free oocytes either intact or deprived of their vitelline membrane by pronase treatment. The same argument applies to another set of experiments where we always obtained 95 p. 100 meiosis, 
whatever the volume of our assay was (200 follicle-free oocytes in 1-10 or $100 \mathrm{ml}$ of $90 \mathrm{mMCa}^{2+} \mathrm{ASW}$ ), whereas a $1 / 10$ th dilution taken from the $1 \mathrm{ml}$ vehicle remained ineffective on control oocytes. However, it could be argued that parasitic follicular cells would not act by releasing 1-MeAde but directly, through contact with the oocyte surface. This eventuality is quite unlikely however since it implies that each oocyte must bear at least one follicular cell, which could have hardly escape careful observation. Even if this was true, our experiments dealing with prefertilized or preactivated oocytes definitively make such a proposition untenable.

More interesting is the fact that we were able to show unequivocally, by using the photoprotein aequorin, that both the hormone 1-MeAde and the $\mathrm{Ca}^{2+}$ ions bring about a transient release of free calcium inside the cell. Results obtained in presence of CaMgFSW supplemented with EGTA, EDTA or lanthanum chloride and voltage clamp data strongly suggest that $\mathrm{Ca}^{2+}$ ions and 1-MeAde may act through different mechanisms, namely the activation of transmembranar $\mathrm{Ca}^{2+}$ channels or the release of $\mathrm{Ca}^{2+}$ ions from an internal store. The fact that $\mathrm{D} 600$ and isoptin block both responses indicates moreover that these drugs may directly affect the intracellular $\mathrm{Ca}^{2+}$ ion equilibrium in addition to their well known effect on the $\mathrm{Ca}^{2+}$ channel.

In fact, the intracellular $\mathrm{Ca}^{2+}$ release induced by 1-MeAde application represents the most rapid response to this hormone known so far. It occurs indeed in less than $1 \mathrm{sec}$, while changes in the membrane potential cannot be detected, in the best case, before some $15 \mathrm{sec}$ after hormone addition (Moreau and Cheval, 1976). That this release is indeed the efficient trigger for meiosis reinitiation is attested by our finding that inhibiting threshold free $\mathrm{Ca}^{2+}$ peak truly blocks this process. Other events need however to be simultaneously triggered since the hormone-dependent period always greatly exceeds flash duration. Among the events, the most important one seems to be the activation of endogeneous protein kinases which can be detected in about $3 \mathrm{~min}$ and leads to cortical protein phosphorylation (Guerrier ef al., 1977). This sequence seems to fit quite well with that one can trace from the study of meiosis reinitiation in amphibians (Moreau et al., 1976a, b; Maller and Krebs, 1977 ; Shorderet-Slatkine and Shorderet, 1976).

Another important feature of the present experiments is to show that different threshold values resulting from the same stimulus can lead to quite different effects. Thus, the $\mathrm{Ca}^{2+}$ release needed to obtain nuclear maturation is far less important than that required for ionophore-induced activation. Since both reactions can be triggered independently and successively, this may indicate a different localization for the $\mathrm{Ca}^{2+}$ release or a difference in the responsiveness or localization of the recipient translating structures. Work is now in progress to answer this question.

\footnotetext{
$27^{\mathrm{e}}$ Congrès international des Sciences physiologiques, Symposium "Germ and somatic cell interaction " Paris, 21-23 juillet 1977.
}

Acknowledgments. - We are very grateful to Dr C. C. Ashley for guidance inhandling aequorin. This investigation was supported by the DGRST (ACC 75.70782) and by a Royal Society fellowship awarded to M. M. during his stay at Oxford, U. K. 
Résumé. Des expériences in vitro indiquent que la maturation spontanée des ovocytes de Marthasterias glacialis résulte de la libération d'un important stock de 1-méthyladénine présent dans les cellules folliculaires. Des ovocytes prélevés en début de saison et débarrassés de leurs cellules folliculaires peuvent cependant reprendre leur évolution méiotique sous l'action d'une élévation de la concentration du calcium extracellulaire. II en résulte une variation transitoire du calcium libre intracellulaire qui peut être suivi après injection d'aequorine et qui correspond sensiblement à la variation introduite par action de la 1-méthyladénine. Cette hormone se révèle efficace en l'absence complète de calcium et de magnésium dans le milieu extérieur. Maturation nucléaire et réaction corticale (fécondation ou ionophore A 23187) peuvent être déclenchées indépendamment. Le pic de calcium libre qui marque l'entrée en maturation apparaît moins d'une seconde après l'application du stimulus efficace ( $\mathrm{Ca}^{2+}$ ou 1-MeAde). Il est environ 20 fois plus faible que le pic ionophore et correspond à une variation de l'ordre de 0,5 à $1,5 \mu \mathrm{M}$. L'inhibition simultanée de la réponse calcique et de la méïose par le D 600 ou l'EGTA suggère fortement que le pic calcique constitue le stimulus primaire responsable de la levée d'inhibition de la méiose.

\section{References}

CAYER M. L., KISHIMOTO T., KANATANI H., 1975. Formation of the fertilization membrane by insemination of immature starfish oocytes pretreated with calcium-free seawater. Develop. Growth Diff., 17, 119-125.

CLOUD J., SCHUETZ A. W., 1973. Spontaneous maturation of starfish oocytes : role of calcium ions and follicle cells. Exp. Cell Res., 79, 446-450.

CHAMBERS E. L., PRESSMAN B. C., ROSE B., 1974. The activation of sea urchin eggs by the divalent ionophores A 23187 and X-537 A. Biochem. Biophys. Res. Commun., 60, 126-132.

DALCQ A., 1925. Recherches expérimentales et cytologiques sur la maturation ef l'activation de l'œu d'Asterias glacialis. Arch. Biol., 34, 507-674.

DALCQ A., 1928. Les bases physiologiques de la fécondation ef de la parthénogenèse, Presses Universitaires, Paris.

DORÉE M., GUERRIER P., 1975. Site of action of 1-méthyladenine in inducing oocyte maturation in starfish. Exp. Cell Res., 96, 296-300.

GUERRIER P., DORÉE M., 1975. Hormonal control of reinitiation of meiosis in Starfish. The requirement of 1-methyladenine during nuclear maturation. Develop. Biol., 47, 341-348.

GUERRIER P., MOREAU M., DORÉE M., 1977. Hormonal control of meiosis in starfish : stimulation of protein phosphorylation induced by 1-methyladenine. Mol. cell. Endocrinol., 7, 137-150.

HARVEY E. B., 1956. The american Arbacia and other sea urchins. Princeton Univ. Press, New Jersey.

HIRAI S., KUBOTA J., KANATANI H., 1971. Induction of cytoplasmic maturation by 1-methyladenine in starfish oocytes after removal of the germinal vesicle. Exp. Cell Res., 68, 137-143.

IKEGAMI S., OKADA T. S., KOIDE S. S., 1976. On the role of calcium ions in oocyte maturation in the polychaete Chaetopterus pergamentaceus. Develop. Growth Differ., 18, 33-43.

KANATANI H., 1964. Spawning of starfish : action of gamete shedding substances obtained from radial nerves. Science (Wash.), 146, 1177-1179.

KANATANI H., HIRAMOTO H., 1970. Site of action of 1-methyladenine in inducing oocyte maturation in starfish. Exp. Cell Res., 61, 280-284.

KANATANI H., SHIRAI H., 1967. In vitro production of meiosis-inducing substance by nerve extract in ovary of starfish. Nature (Lond.), 216, 284-286.

KANATANI H., SHIRAI H., 1969. Mechanism of starfish spawning. Il. Some aspects of action of a neural substance obtained from radial nerve. Biol. Bull., 137, 297-311.

KISHIMOTO T., KANATANI H., 1976. Cytoplasmic factor responsible for germinal vesicle breakdown and meiotic maturation in starfish oocyte. Nafure (Lond.) 260, 321-322.

KISHIMOTO T., CAYER M. L., KANATANI H., 1976. Starfish oocyte maturation and reduction of disulfide bond on oocyte surface. Exp. Cell Res., 101, 104-110. 
KOHLHARDT M., BAUER B., KRAUSE B., FLECKENSTEIN A., 1972. New selective inhibitors of the transmembrane $\mathrm{Ca}$ conductivity in mammalian myocardial fibres. Studies with the voltage clamp technique. Experientia, 28, 288-289.

MALLER J. L., KREBS E. G., 1977. Progesterone stimulated meiotic cell division in Xenopus oocytes. J. biol. Chem., 252, 1712-1718.

MOORE L. E., COLE K. S., 1963. Voltage clamp techniques. In NASTUK W. L., Physical Techniques in Biological Research, 6, Acad. Press, New-York.

MOREAU M., CHEVAL J., 1976. Electrical properties of the starfish oocyte membranes. J. Physiol. (Paris), 72, 293-300.

MOREAU M., DORÉE M., GUERRIER P., 1976a. - Electrophoretic introduction of calcium ions into the cortex of Xenopus laevis oocytes triggers meiosis reinitiation. J. exp. Zool., 197, 443-449.

MOREAU M., GUERRIER P., DORÉE M., 1976b. Induction of meiosis reinitiation in Xenopus laevis oocytes after injection of heterologous protein kinase and phosphorylase kinase. J. exp. Zool., 197, 435-442.

PASTEELS J., 1935. Recherches sur le déterminisme de l'entrée en maturation de l'œuf chez divers Invertébrés marins. Arch. Biol., 46, 229-262.

PASTEELS J., 1938. Le rôle du calcium dans l'activation de l'œuf de Pholade. Trov. Stat. Zool. Wimereux, 13, 515-530.

PAUL M., 1975. Release of acid and changes in light scattering properties following fertilization of Urechis caupo eggs. Develop. Biol. 43, 299-312.

RIDGWAY E. B., GILKEY J. C., JAFFEE L. F., 1976. Free calcium increases explosively in activating medaka eggs. J. Cell Biol., 70, $227 a$.

SHAPIRO H., 1941. Centrifugal elongation of cells, and some conditions governing the return to sphericity and cleavage time. J. cell. comp. Physiol., 18, 61-78.

SHIRAI H., 1974. Effect of L-phenylalanine on 1-methyladenine production and spontaneous oocyte maturation in starfish. Exp. Cell Res., 87, 31-38.

SHORDERET-SLATKINE S., SCHORDERET M., 1976. Maturation in vivo de l'ovocyte de Xenopus laevis sous l'effet d'agents pharmacologiques du type propanolol. C. R. Acad. Sci. Paris, Série D 282, $1733-1736$.

SCHUETZ A. W., 1969. Chemical properties and physiological actions of a starfish radial nerve factor and ovarian factor. Gen. comp. Endocrinol., 12, 209-221.

SCHUETZ A. W., 1975a. Induction of nuclear breakdown and meiosis in Spisula solidissima oocytes by calcium ionophore. J. exp. Zool., 191, 433-440.

SCHUETZ A. W., 1975b. Cytoplasmic activation starfish oocytes by sperm and divalent ionophore A 23187. J. Cell Biol., 66, 86-94.

SCHUETZ A. W., BIGGERS J. D., 1967. Regulation of germinal vesicle breakdown in starfish oocytes. Exp. Cell Res., 46, 624-628.

STEINHARDT R. A., LUNDIN L., MAZIA D., 1971. Bioelectric responses of the Echinoderm egg to fertilization. Proc. nat. Acad. Sci. USA, 68, 2426-2430.

STEINHARDT R. A., EPEL D., 1974. Activation of sea urchin eggs by calcium ionophore. Proc. nat. Acod. Sci. USA, 71, 1915-1919.

STEINHARDT R. A., EPEL D., CARROLL E. J., Jr, YANAGIMACHI R., 1974. Is calcium ionophore a universal activator for unfertilized eggs? Nature (Lond.), 252, 41-43.

STEINHARDT R., ZUCKER R., SCHATTEN G., 1977. Intracellular calcium release at fertilization in the sea urchin egg. Develop. Biol., 58, 186-196.

WASSERMANN J., MASUI Y., 1975. Initiation of meiotic maturation in Xenopus laevis oocytes by the combination of divalent cations and ionophore A 23187. J. exp. Zool., 193, 369-375. 